University of Rzeszow

\title{
PREVENTION OF EMPLOYEE'S MENTAL HEALTH AND EMPLOYMENT LAW
}

\begin{abstract}
The article is devoted to selected issues of protection of mental health of an employee. This issue has a very practical value, but so far, the proposed topic has not received too many scientific studies conducted through the prism of Polish labour law regulations. The text, in addition to the author's thoughts, has been enriched with guidelines for the promotion of mental health published by the European Commission in 2014 in a document entitled Promoting Mental Health in the Workplace.
\end{abstract}

Słowa kluczowe: pracownik, zatrudnienie, zdrowie psychiczne, ochrona, prawo pracy

Keywords: employee, employment, mental health, protection, labour law

ASJC: 3308, JEL: K31

\section{Introduction}

Regulations, the primary goal of which is to protect the life and health of the employee, are one of the most important components of the individual labour law. In the doctrine of the subject, they constitute the core of the regulations included in the so-called protective function of labour law. The idea of this function, recognized by a substantial part of the Polish labour law doctrine as the most important and characteristic of this branch of law, comes down to the need to legally privilege the employee in the employment relationship as an economically and socially weaker entity (Liszcz 2019, p. 31). These regulations should, in their original intention, emphasize the subjective approach to the employee in relationship resulting from the established employment relationship, which by definition should exclude his objectification (this point of view is characteristic mainly to Catholic social science; cf. John Paul II 1995; Liszcz 2018, pp. 139-147; Musiała 2019). The subjectivity of an employee, analysed through the prism of the employer that employs him, therefore comes down to the fact that the employing entity fulfils a number of obligations included in the labour code, which should be 
implemented with respect for the dignity of the employee. The Polish legislator in the part of the Labour Code entitled Basic Principles of Labour Law, in the Art. 11 (1) of the Act of 26 June 1974, Dz.U. 2020, item 1320 consolidated text (hereinafter referred to as: the Labour Code, l.c.), included a provision according to which it obliges the employer to respect the dignity and other personal rights of the employee. This regulation is not reciprocal, in the sense that the Polish Labour Code does not include a provision obliging the employee to respect the dignity of the employer. This obligation, however, can be enforced on the basis of other regulations, but this thread, as a side issue for the objectives set in the study, will not be analysed further. Secondly, bearing in mind the proposed title of the study, it is worth emphasizing that the wording of this provision indicating its mandatory character. In this case, the legislator does not leave either an alternative to the behaviour or omissions of the employer, which would justify the result in the form of, for example, failure to respect the dignity and other personal rights of the employee. The structure of the said provision is of a fundamental nature, requiring the employer to take specific actions aimed at eliminating undesirable effects. Similarly, because with the same uncompromising attitude, the principle expressed in the Art. 15 of the Labour Code, which implies the employer's obligation to provide employees with safe and hygienic working conditions (it should be noted that the issues of occupational health and safety have also become the subject of the entire section X of the Labour Code). Also, in this case, taking into account both the life and health of the employee, as it is essentially the obligation to ensure safe and hygienic working conditions, the legislator does not leave the employer the right to any exceptions. At this stage, it should be noted that the obligation to provide the employee with safe and hygienic working conditions does not include events occurring outside the place of work, or more broadly outside the workplace, on the way home from work (see judgment of the Supreme Court of 12 December 2019, I PK 205/18, Legalis 2277367). Therefore, the proposed issues related to the protection of the mental health of an employee essentially fit into the implementation of both of the above-mentioned basic principles. Nevertheless, the assumed goal in this case will become synoptic analysis of the applicable regulations in the field of Polish labour law and an attempt to answer the question to what extent they actually provide protection in the field of mental health of the employee.

\section{The concept of health and Polish law: Selected aspects}

The conducted analysis requires clarification of the basic concepts constituting the main subject of protection, on which this study is also indirectly based. Undoubtedly, such a term will be the definition of mental health. However, before this concept is analysed in detail, it should be noted that the Polish Labour Code does not include its legal definition. Moreover, the content of the Labour Code does not include a legal definition of health, although this concept is mentioned many times as a legally protected value. Most likely is that the legislator resigned from including even the basic definition of 
health in the content of the code, assuming that it was a non-legal term. In view of the above, it will be reasonable to refer to its common understanding. Therefore, according to the Dictionary of the Polish Language, the concept of health is understood as "a good, normal state of the human, animal, plant organism, the state of an organism not affected by disease" (Sobol 1994, p. 1140).

It results from the above-mentioned definition that the state of health by definition excludes the occurrence of a disease, moreover, health is considered to be the norm in the functioning of a living organism. However, the above definition, apart from the common understanding of well-being, does not indicate the individual elements which constituent its components. Therefore, bearing in mind the main subject of the analysis of this study, it will be necessary to provide a broader and more detailed definition of health developed by the World Health Organization (WHO). According to the position adopted by the WHO in the 1946 "health is the fullness of physical, mental and social well-being, and not only the absence of disease and ailments (disabilities)" (Woynarowska 2007, pp. $19 \mathrm{ff}$; see also WHO 2001). The above definition implies not only the elimination of the disease phenomenon, but a wider spectrum of its impact, namely: emphasizing that its content also includes the active aspect, which is generally accepted well-being. From a practical point of view, which is also one of the reasons for this study, it means not only fighting the disease, but also maintaining and strengthening good health (Gałecki et al. 2016, p. 20). For the adopted considerations, the indicated definition seems to be a turning point, because it is the basis for not only the commonly emphasized biological dimension of health taking the form of the absence of disease, but also its equally important psychological dimension. In the literature on this issue, it was noted that in the mental dimension, mental health is additionally distinguished, responsible for mental processes, but also emotional health, related to the ability to experience feelings and emotions (Maszczak 2005, p. 74). In the quoted WHO's definition, in addition to the indicated components of the concept of health, its social dimension is also emphasized as a third coexisting and necessary complementary element. The social dimension translates into the ability to enter into and maintain relationships with other people. The WHO definition already at this stage allows for a thesis that the concept of health is a multifaceted issue, and therefore its full dimension consists of mutually interacting spheres, i.e. physical, mental and social. The above division will allow for the continuation of the considerations, which, however, will be focused on the psychological sphere.

As already indicated, in the Polish Labour Code, apart from the lack of a definition of health, the definition of mental health was not included. In addition, it should be noted that the Polish legislator does not use this concept in the content of the Labour Code even once, although in several provisions it emphasizes the need to protect the health of an employee against disorder. Such regulations will be included in part of the provision relating to mobbing, the occurrence of which most often leads to harm in the form of mental health disorder of the employee. Despite the lack of a legal definition of mental health in the Polish Labour Code, this concept has been recognized as 
the essential one in another act, namely the Act of 19 August 1994 on mental health protection (Dz.U. 2020, item 685 consolidated text). This act is a legal act intended to provide appropriate guarantees for the implementation of the principle of respect for civil rights and freedoms. Therefore, as pointed out by the Supreme Court, the cases regulated by its provisions are, by definition, cases in the field of personal law (see decision of the Supreme Court of 25 January 2001, III CKN 1454/00, OSNC 2001, No. 7-8, item 116, p. 84). It is true that the content of this law does not include a legal definition of mental health, but its preamble states that mental health is a fundamental, and therefore the basic, personal good of every human being. The qualification of mental health to the category of personal rights allows referring to detailed regulations related to their protection, guaranteed in Polish law, also using the civil way. Mental health, as pointed out in the literature, is a relative rather than absolute condition (Shahrokh, Hales 2009). In view of the above, among the methods of protection of personal rights, the Polish legislator mentions, first of all, the failure to act in breach of a given personal interest, i.e. preventive measures. However, omission may only take place when a specific personal interest has not yet been infringed, but as a result of such violations it becomes actually and really threatened. Subsequently, the remedial measure will be to complete the activities necessary to eliminate the effects of violations of a given personal interest. Pursuant to the applicable regulations, a person whose personal rights have been violated may also demand monetary compensation or payment for an indicated social purpose. In addition, if a property damage becomes a result of the breach of a specific personal interest, the aggrieved party may, under general rules (i.e. Art. $24 \$ 2$ of the Civil Code Act of 23 April 1964, Dz.U. 2020, item 1740 consolidated text, as amended), demand its compensation. Basically, under the Civil Code, the legislator presumed the unlawfulness of infringement of a personal interest. This presumption, however, is rebuttable, i.e. in the case of substantiating the right to a specific action, which has been recognized as an action resulting in the infringement of a specific personal interest. In view of the above, a person who claims that his personal interest has been violated, e.g. in the form of a violation of his mental health, does not have to prove it was unlawful, as in such a case the burden of proving such a fact rests with the person who derives legal consequences from this fact. Pursuant to the above-mentioned principle contained in the Labour Code, the employer is responsible for protecting the employee's personal rights. On the other hand, referring to the literal wording of the preamble to the Protection of Mental Health Act, it follows that the protection of the rights of people with mental disorders is the responsibility of the state, government and local government administration bodies (Korzan 1996, p. 23). Therefore, it seems that it should be understood in the meaning that state interference becomes possible only after the mental structure of an employee is violated. On the other hand, when an employment relationship is established, the employer's duty will be to respect and protect his mental health, which is to be achieved by ensuring safe and hygienic working conditions. Collectively, these activities can be defined as preventive, remedial, aimed in this particular case at maintaining the full health of the employee, also in the sphere of his psyche. In this respect, 
undertaking targeted preventive actions by the employer with whom the employee spends a significant part of his conscious life, fulfils the assumptions referred to collectively in Art. 1 of the Protection of Mental Health Act. Namely, in accordance with the will of the legislator included in Art. 1 (2) of the Protection of Mental Health Act, as an alternative, because in addition to public administration bodies, "other natural and legal persons" may also participate in the activities related to protection of mental health. In view of the above, it seems that in this case there are no obstacles to qualify employers within the meaning of Art. 3 of the Labour Code.

An argument in favour of the rightness of the above qualification is also the tendency expressed by the European Commission in the document entitled Promoting Mental Health in the Workplace. This document provides guidance on the comprehensive approach of European employers employing employees. Its content was based on an analysis related to the occurrence of the effects of violations of the mental health of employees, both from the point of view of their own interests, and the multidimensional risk borne by employers in this respect. Already in the introduction to this document, the Commission emphasizes, among others, the important role of employers in the scope of both solving mental health problems of employees and their psychophysical well-being and ways of mitigating the risk, up to the broadly understood promotion of mental health in the workplace. The content of the document also includes specific examples of actions taken by employers to improve this sphere of employees' lives. Therefore, this publication should be considered an important and practical tool aimed at providing an integrated framework for promoting mental health in the workplace and presenting examples of good practices that were found to be effective in the analysed area. Finally, it should be noted that the content of the EC document, along with many other terms contained in the glossary, also includes the very definition of mental health. It means collectively: a state of well-being in which a person uses his abilities, can deal with stress in everyday life, can work efficiently and productively, and is able to contribute to the life of the community. Therefore, it seems that its structure is close to the assumptions of the mentioned definition of health proposed by the WHO.

\section{Selected issues of Polish labour law and the protection of an employee's mental health}

At the outset, it must be pointed out that the issue of the protection of the mental health of an employee in Polish labour law is not an issue to which due attention has been paid. However, this does not mean that, in the current legal Polish system, the Polish labour legislator completely disregards them, although there has undoubtedly been unacceptable marginalisation in this regard. When analysing current regulations, it should be noted that health, and therefore mental health, can be both a criterion on which the establishment and termination of employment will depend. In the first case, it comes down to the finding that the psychophysical well-being of the worker constitutes the 
actual basis for the worker's admission to certain professions. An example of such regulations, which, among the selection requirements mention precisely the appropriate mental state of the future employee, is the Act of 27 July 2001-the law on the system of common courts, Dz.U. 2020, item 2072 consolidated text (hereinafter referred to as: the law on the system of common courts). Basically, Polish legislator, among the necessary elements related to admitting employee to work requires conducting preliminary examinations. However, only some of the provisions contain an additional obligation to target such examination specifically to mental sphere. The aforementioned law on the system of common courts act, in the chapter entitled Appointment to Perform the Position of Judge, refers to the Regulation of the Minister of Justice on medical and psychological examinations of the candidates for the position of judge (more: based on the Art. $57 \$ 10$ of the law on the system of common courts and the regulation of the Minister of Justice of 19 September 2014 on medical and psychological examinations of the candidates for the position of judge, Dz.U. 2018, item 619 consolidated text). The examination of the candidate for the position of judge contain i.a. studies aimed at the overall assessment of health, with a particular focus on the nervous and mental state. After carrying them out, the authorised doctor issues a certificate of the candidate's fitness to perform the duties of judge. These tests can only be carried out by a doctor who meets three criteria altogether, i.e.: entry in the register of doctors carrying out preventive examinations carried out pursuant to the Art. $229 \$ 8$ of the Employment Code, the right to practice, as well as at least five years of service in doctor's profession. On the other hand, the psychological examination of the candidate is carried out by an authorised psychologist, who was entered in the register kept by the provincial police commander pursuant to Art. 15c(2) of the Act of 21 May 1999-the law on weapons and ammunition (Dz.U. 2020, item 955 consolidated text). Such studies, on the other hand, include a direct interview and observation of the candidate carried out using diagnostic tools. At that time, the psychologist defines and describes the personality features of the candidate regarding cognitive and social skills, taking into account the ability of assessing the situation independently and making decisions and his/her resistance to stress. The authorised psychologist on the basis of the results of the examinations, issues a so-called psychological certificate about the candidate's ability to perform the duties of a judge, in terms of predisposition and psychological skills. Nevertheless, this law is one of the few that provides a basis for verifying the mental sphere of a future employee. This means that the employer cannot have such tests carried out without clearly defined legal basis.

However, when examining the content of the Polish Labour Code in terms of issues related to the protection of the mental health of the employee during ongoing employment, it is impossible to ignore the provision regarding mobbing. Undoubtedly, mobbing, which according to the Polish Labour Code means: actions or behaviour concerning the employee or directed against the employee, results in a violation of his/her mental and emotional fitness (Bosak-Sojka, Maron 2018a, pp. 196-210; 2018b, pp. 137-146; 2018c, pp. 676-686). By characterising this phenomenon, the legislator itself emphasises that it consists in persistent and prolonged harassment and intimidation of the employee, 
causing at employee underestimation of his/her professional suitability, humiliation, stultification, isolation or elimination from the team of colleagues. Mobbing is therefore referred to as psychological violence, which is a particular type of pathology at the work site (Bosak 2010, pp. 163-169). Accordingly, when an employer decides to employ an employee is obliged to provide him/her with safe and hygienic working conditions, that is to say, working conditions which are free from practices fulfilling mobbing features. In Polish labour law, the obligation to prevent mobbing has the extent of an obligation to act diligently, and in fulfilling the above obligation-a work environment free from mobbing. This issue therefore appears to be one of the key issues which the primary objective is to protect the mental health of the employee. It is true that, apart from the general anti-mobbing order, which in any case burdens the employer, Polish legislature has not decided to specify the measures to do so. Therefore, judicial case law emphasises the special training role of informing about the danger and consequences of mobbing, as well as the need to put in place procedures enabling to detect and eradicate this pathological phenomenon (see judgment of the Supreme Court of 3 August 2011, I PK 35/11, OSNAPiUS 2012, No. 19-20, item 238, p. 814). However, the choice of appropriate and effective measures to eliminate mobbing the legislator leaves to each employer individually. Recent case law highlights also the employer's obligation to shape the principles of social coexistence in the workplace, the deficit of which is one of the more serious causes leading to degradation of employees' mental health. In addition to general obligations such as the duty to counteract mobbing, the duty to respect the dignity and other personal rights of the employee, specific obligations such as ensuring a good working atmosphere, counteracting conflicts, preventing violations of workers' dignity are shaped. It follows from the further part of the judgment in question that it is inadmissible, since it is in opposition to the principles of social coexistence to tolerate employees using abusive, vulgar, insulting or obscene expressions to each other (see judgment of the Supreme Court of 30 August 2018, I PK 184/17, Legalis 1819161).

Issues relating to the protection of the health of the employees in mental sphere also arise indirectly from the content of certain implementing acts governing detailed rules relating to the conditions of employment of vulnerable groups of employees. According to their content, certain types of work result in psychosocial risks and do not affect positively on the development or psychophysical condition of employees. In this case, these prohibitions are addressed to juvenile employees employed both for the purpose of vocational training (see the regulation of the Council of Ministers of 24 August 2004 concerning the list of work forbidden to juveniles and conditions of engaging them to do some jobs, Dz.U. 2016, item 1509 consolidated text) as well as non-strenuous work (this prohibition is one of the criteria characterizing so-called light work; see Art. 2001 $\$ 2$ l.c.) and women, including pregnant women (the regulation of the Council of Ministers of 3 April 2017 on the list of burdensome, hazardous or harmful work for the health of pregnant women and women breastfeeding, Dz.U. 2017, item 796). 


\section{References}

Bosak M. (2010) Zjawisko mobbingu jako patologia pracy: kilka uwag na tle regulacji zawartych $w$ kodeksie pracy, "Ius et Administratio," Speccial Issue.

Bosak-Sojka M., Maroń A. (2018a) Mobbing jako przykład zagrożenia dla życia i zdrowia pracownika [in:] D. Semków (red.), Przestępstwa przeciwko życiu i zdrowiu. Aspekty prawne, kryminologiczne i kryminalistyczne, Warszawa.

Bosak-Sojka M., Maroń A. (2018b) Mobbing jako zagrożenie dla zdrowia pracownika w świetle regulacji polskiego prawa pracy [in:] M. Dolobáč, M. Seilerová (red.), Starostlivost’o zdravie zamestnancov, Košice.

Bosak-Sojka M., Maroń A. (2018c) Przyczyny mobbingu w administracji publicznej [in:] E. Ura, E. Feret, S. Pieprzny (red.), Zagadnienia bezpieczeństwa i porzadku publicznego w jednostkach samorządu terytorialnego, Rzeszów.

John Paul II (1995) Encyklika Labourem Excercens. O pracy ludzkiej, Wrocław.

Gałecki P., Bobińska K., Eichstaedt K. (2016) Ustawa o ochronie zdrowia psychicznego. Komentarz, Warszawa.

Korzan K. (1996) Postępowanie w sprawach ochrony zdrowia psychicznego, "Rejent," nr 6.

Liszcz T. (2018) Aksjologiczne podstawy prawa pracy. Zarys problematyki, Lublin.

Liszcz T. (2019) Prawo pracy, Warszawa.

Maszczak T. (2005) Zdrowie jako wartość uniwersalna (Health as a universal value), "Roczniki Naukowe AWF w Poznaniu," z. 54.

Musiała A. (2019) Polskie prawo pracy a społeczna nauka Kościoła. Studium prawno-społeczne, Poznań.

Shahrokh N.C., Hales R.E. (2009) Amerykańskisłownikpsychiatryczny, B. Łoza, A. Czernikiewicz(red.), Wrocław.

Sobol E. (red.) (1994) Mały słownik języka polskiego, Warszawa.

WHO (2001), Mental Health: Strengthening Mental Health Promotion, Fact sheet $\mathrm{N}^{\circ} 220$, https:// mindyourmindproject.org/wp-content/uploads/2014/11/WHO-Statement-on-MentalHealth-Promotion.pdf (access: 18 November 2020).

Woynarowska B. (2007) Edukacja zdrowotna. Podręcznik akademicki, Warszawa.

\section{Court sentences}

Decision of the Supreme Court of 25 January 2001, III CKN 1454/00, OSNC 2001, No. 7-8, item 116.

Judgment of the Supreme Court of 3 August 2011, I PK 35/11, OSNAPiUS 2012, No. 19-20, item 238.

Judgment of the Supreme Court of 30 August 2018, I PK 184/17, Legalis 1819161.

Judgment of the Supreme Court of 12 December 2019, I PK 205/18, Legalis 2277367. 


\section{Legal acts}

The Civil Code Act of 23 April 1964, Dz.U. 2020, item 1740 consolidated text, as amended.

The Labour Code Act of 26 June 1974, Dz.U. 2020, item 1320 consolidated text.

The Act of 19 August 1994 on mental health protection, Dz.U. 2020, item 685 consolidated text.

The Act of 21 May 1999-the law on weapons and ammunition, Dz.U. 2020, item 955 consolidated text.

The Act of 27 July 2001-the law on the system of common courts, Dz.U. 2020, item 2072 consolidated text.

The regulation of the Council of Ministers of 24 August 2004 concerning the list of work forbidden to juveniles and conditions of engaging them to do some jobs, Dz.U. 2016, item 1509 consolidated text.

The regulation of the Minister of Justice of 19 September 2014 on medical and psychological examinations of the candidates for the position of judge, Dz.U. 2018, item 619 consolidated text.

The regulation of the Council of Ministers of 3 April 2017 on the list of burdensome, hazardous or harmful work for the health of pregnant women and women breastfeeding, Dz.U. 2017, item 796. 